\title{
Author Correction: TRPS1 shapes YAP/TEAD- dependent transcription in breast cancer cells
}

\author{
Dana Elster ${ }^{1}$, Marie Tollot ${ }^{1}$, Karin Schlegelmilch (10 ${ }^{2}$, Alessandro Ori ${ }^{1}$, Andreas Rosenwald ${ }^{3}$, Erik Sahai (i) ${ }^{2} \&$ \\ Björn von Eyss (1) ${ }^{1}$
}

Correction to: Nature Communications; https://doi.org/10.1038/s41467-018-05370-7; published online 6 August 2018

In the original version of this article, financial support was not fully acknowledged. The PDF and HTML versions of the Article have now been corrected to include the following:

"This work was supported by the Francis Crick Institute, which receives its core funding from Cancer Research UK (FC001144), the UK Medical Research Council (FC001144), and the Wellcome Trust (FC001144)."

Published online: 12 September 2018

\begin{abstract}
(c) Open Access This article is licensed under a Creative Commons Attribution 4.0 International License, which permits use, sharing, adaptation, distribution and reproduction in any medium or format, as long as you give appropriate credit to the original author(s) and the source, provide a link to the Creative Commons license, and indicate if changes were made. The images or other third party material in this article are included in the article's Creative Commons license, unless indicated otherwise in a credit

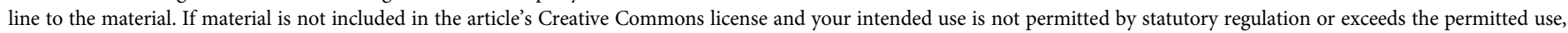
you will need to obtain permission directly from the copyright holder. To view a copy of this license, visit http://creativecommons.org/licenses/by/4.0/.
\end{abstract}

(C) The Author(s) 2018

\footnotetext{
${ }^{1}$ Leibniz Institute on Aging, Fritz Lipmann Institute e.V., Beutenbergstr. 11, 07745 Jena, Germany. ${ }^{2}$ Tumour Cell Biology Laboratory, Francis Crick Institute, 1 Midland Road, London NW1 1AT, UK. ${ }^{3}$ Institute of Pathology, University of Würzburg, and Comprehensive Cancer Center Mainfranken (CCCMF), JosefSchneider-Str. 2, 97080 Würzburg, Germany. Correspondence and requests for materials should be addressed to B.E. (email: bjoern.voneyss@leibniz-fli.de)
} 